\title{
A atuação do Brasil no âmbito da Cooperação Internacional para o Desenvolvimento: percepções sobre a "Era Lula"
}

\author{
Brazil's actions in the framework of International Development \\ Cooperation: perceptions about the "Lula Era"
}

\section{El papel de Brasil en la Cooperación Internacional para el Desarrollo: percepciones sobre la "Era Lula}

Tacilla da Costa e Sá Siqueira Santos

Professora Adjunta do Bacharelado de

Relações Internacionais, Instituto de Humanidades e Letras da Universidade da Integração Internacional da Lusofonia Afro-

Brasileira (UNILAB)

São Francisco do Conde, Bahia, Brasil

E-mail: tacillasiqueira@unilab.edu.br

Orcid: 0000-0002-5768-8649

\begin{abstract}
Resumo: No início dos anos 2000, sob a liderança do Presidente Lula, o Brasil se projetou internacionalmente, com grande força, pleiteando um lugar de liderança no chamado Eixo Sul. O programa proposto pela coalizão encabeçada pelo Partido dos Trabalhadores (PT) - responsável pela eleição de Lula - previa uma atuação mais assertiva, com o exercício de uma política externa relacionada a uma política de desenvolvimento nacional. A expansão da cooperação internacional brasileira, nessa perspectiva, refletia o avanço do seu poder econômico e político no mundo, e a construção feita pelo país na busca de ocupar outro lugar no cenário internacional que tinha como uma das suas bases a atuação no âmbito da cooperação internacional para o desenvolvimento, em especial, na sua vertente Sul-Sul. Este trabalho, objetiva, portanto, um transitar pela participação do Brasil na cooperação internacional, buscando compreender e analisar criticamente a atuação oficial brasileira no âmbito da Cooperação Internacional para o Desenvolvimento, em especial na sua vertente Sul-Sul, durante os governos do presidente Lula.
\end{abstract}

Palavras-chave: Cooperação Internacional; Cooperação Sul-Sul; Brasil. 
Abstract: At the beginning of the 2000's, under the leadership of President Lula, Brazil emerged as a strong international player, pleading its leadership in the so-called Global South. Its program proposed by the coalition led by the Workers Party (Partido dos Trabalhadores - PT) - which was responsible for Lula's victory in the elections - attempted to build an assertive foreign policy strongly aligned with national development. In this perspective, the expansion of Brazilian International Cooperation reflected the advancement of Brazilian economic and political power worldwide and its efforts to achieve an important role within the International Cooperation for Development, especially as an important player within South-South Cooperation. The present work aims to analyze the path of Brazilian participation at the International Cooperation, seeking to achieve a critical understanding of Brazil's official undertake within the International Cooperation for Development, especially as related to its role in the South-South Cooperation during the mandate of President Luiz Inácio Lula da Silva.

Keywords: International Cooperation; South-South Cooperation; Brazil.

Resumen: A principios de la década de 2000, bajo el liderazgo del presidente Lula, Brasil se proyectó internacionalmente con gran fuerza, reclamando un lugar de liderazgo en el Ilamado Eje Sur. El programa propuesto por la coalición encabezada por el Partido de los Trabajadores (PT), responsable de la elección de Lula, preveía un papel más asertivo, con el ejercicio de una política exterior relacionada con una política de desarrollo nacional. La expansión de la cooperación internacional brasileña, en esta perspectiva, reflejó el avance de su poder económico y político en el mundo, y la construcción realizada por el país en busca de ocupar otro lugar en el escenario internacional que tuvo como una de sus bases la actuación en el campo de la cooperación internacional para el desarrollo, especialmente en su vertiente Sur-Sur. Este trabajo, por lo tanto, tiene como objetivo explorar la participación de Brasil en la cooperación internacional, buscando comprender y analizar críticamente la actuación oficial brasileña en el ámbito de la Cooperación Internacional para el Desarrollo, especialmente en su dimensión Sur-Sur, durante los gobiernos del presidente Lula.

Palabras clave: Cooperación internacional; Cooperación Sur-Sur; Brasil. 


\section{INTRODUÇÃO}

A trajetória cumprida pelo Brasil no âmbito de sua política externa de um modo geral, e na cooperação internacional, particularmente, e as mudanças sistêmicas que marcaram a primeira década dos anos 2000 , em especial o período no qual o país esteve sob a presidência de Luiz Inácio "Lula" da Silva (2003-2010), implicaram em uma transformação do seu papel e da percepção de outros Estados sobre a sua atuação e do lugar ocupado pelo país na geopolítica mundial e regional.

Neste sentido, se historicamente o Brasil era classificado como "receptor" de cooperação (BARBOSA, 2011; CORDEIRO, 2012; CORRÊA, 2011; GONÇALVES, 2011; PUENTE, 2010), naquele momento histórico, na condição de "país em desenvolvimento que atingiu um nível intermediário de renda e um Produto Interno Bruto (PIB)" e passou a ser situado "entre as dez maiores economias do planeta", o Brasil vivenciou uma dupla posição de "recebedor" e de "prestador" (CORRÊA, 2011; KLEIMAN; CEZARIO, 2012) ou, segundo a terminologia do Comitê de Ajuda ao Desenvolvimento da Organização para Cooperação e Desenvolvimento Econômico $(\mathrm{OCDE})$, que o próprio governo brasileiro contestava ${ }^{1}$, de "beneficiário" e "doador" 2 de uma cooperação que emergia cada vez com mais força no cenário internacional,

1 Utilizamos as terminologias "doador", "prestador" e "receptor", "recebedor" de cooperação por serem as mais usuais na literatura especializada e as tradicionalmente adotadas pelos países do Comitê de Ajuda ao Desenvolvimento (CAD) da Organização para Cooperação e Desenvolvimento Econômico (OCDE). No entanto, é necessário ressaltar que o governo brasileiro entende a cooperação para o desenvolvimento internacional como uma relação entre semelhantes, descartando, portanto, a ideia de que a relação de cooperação se resuma a uma "interação entre doadores e recebedores". Esta defesa do governo brasileiro está claramente ilustrada no Prefácio do documento "Cooperação Brasileira para o Desenvolvimento Internacional: 2005-2009" (INSTITUTO DE PESQUISA ECONÔMICA APLICADA; AGÊNCIA BRASILEIRA DE COOPERAÇÃO, 2013), assinado pelo então presidente do Brasil, Luiz Inácio "Lula" da Silva e já citado neste trabalho. Deste modo, importa deixar claro que o Brasil não se identifica enquanto um país simplesmente "doador" ou "receptor" no âmbito da CID.

2 Mawdsley $(2010 ; 2011)$ lembra que um dos termos mais precisos para classificar os países que não se constituem em "doadores" tradicionais do sistema de ajuda, mas que passam a destinar recursos no âmbito da cooperação internacional, seria o de "non-DAC donors/partners", em uma referência clara ao fato de não fazerem parte do CAD/OCDE. Reitera, no entanto, que alguns dos atores emergentes preferem tratar as relações de ajuda ou cooperação como "parcerias de desenvolvimento", promovendo conscientemente, deste modo, um discurso de relações horizontais de benefício mútuo, não ingerência e respeito à soberania, ao invés da hierarquia vertical invocada na utilização dos termos "doador" e "receptor". Salienta, ainda, que, no caso específico dos estados do Sul, um termo potencialmente atraente é o de "doadores pós-coloniais". 
marcando o fato de que a "linha" que existia entre "recebedores" e "doadores" de ajuda se tornou embaçada, conforme afirmam Zimmermann e Smith $(2011)^{3}$.

Todas essas mudanças impactaram e foram impactadas pelas relações e alianças que o país construiu internamente e em diálogo com o contexto internacional. Foram, igualmente, um reflexo dos avanços feitos pelo Brasil no que tange a suas políticas sociais - cuja demanda por socialização no âmbito internacional era crescente -, e das posturas assumidas no bojo da sua política externa, que conduziu, em grande parte, a internacionalização destas práticas, na medida em que barganhava outro "lugar" na cena internacional, em uma perspectiva que transitava entre o poder e a solidariedade. Este momento de ebulição pelo qual passava o país e a própria Cooperação Internacional para o Desenvolvimento (CID) trouxe, no entanto, não somente os resultados dos avanços do Brasil nesta seara, mas, também, colocou em discussão questões fundamentais para se compreender a sua relação com um "novo" momento da cooperação internacional.

Conforme sinaliza Milani (2018, p. 267), neste período, as decisões em matéria de política externa fundamentavam-se em uma interpretação bastante singular da política internacional e da relevância dos recursos estratégicos do país, e a política externa brasileira (PEB) esteve baseada em uma visão multipolar de mundo, segundo a qual a globalização e a difusão do poder promoveriam mudanças estruturais na economia mundial, resultando em redistribuição de poder do Ocidente para o Oriente e do Norte para o Sul (MILANI, 2018, p.267). As mudanças na cooperação internacional para o desenvolvimento e a visão de política internacional que constituiu a política externa implementada durante o governo Lula, colocaram, nessa perspectiva, a cooperação Sul-Sul (CSS) empreendida pelo país em lugar de destaque.

3 Segundo Zimmermann e Smith (2011, p. 722), quando foram definidos os Objetivos de Desenvolvimento do Milênio, o mundo parecia dividido entre os países que precisavam alcançar os objetivos então definidos e outros que tinham que ajudá-los na tarefa de alcançar estes objetivos. Dez anos mais tarde, no entanto, a linha entre os "receptores" e "doadores" de ajuda "tornou-se embaçada". Para os autores, o crescimento impressionante de países como China, Índia, Brasil e outras economias emergentes tem sido acompanhado por um crescimento igualmente impressionante na cooperação para o desenvolvimento que fornecem para outros países. 
Neste artigo fazemos uma "trilha" para desvelar a participação do Brasil na cooperação internacional, buscando compreender a atuação oficial brasileira no âmbito da CID, em especial na sua vertente Sul-Sul, durante o governo do presidente Lula. Deste modo, transitamos aqui desde a inserção do Brasil no sistema de cooperação internacional para o desenvolvimento, passando pelas mudanças operadas no país e na própria cooperação que redefiniram a atuação oficial brasileira nesse âmbito; pelas mudanças operadas na cooperação do país a partir do governo Lula; pelas estratégias deste governo no âmbito da Cooperação Sul-Sul para o Desenvolvimento, para, por fim, apresentarmos algumas percepções críticas ao universo que permeou a atuação oficial brasileira na CID, em especial na CSS, durante o período. Para cumprir este percurso partimos da seguinte questão: como se deu a atuação oficial do Brasil na cooperação internacional, particularmente na sua vertente Sul-Sul, durante o governo do presidente Lula?

Este trabalho se propõe, portanto, a captar um fenômeno social, refletindo criticamente sobre ele, podendo, em um primeiro momento, ser caracterizado como de natureza descritivo-analítica e de caráter essencialmente qualitativo. A escolha da metodologia qualitativa acentua a perspectiva de que o fenômeno estudado não pode ser considerado como um fato social imutável, mas como um conjunto de representações e configurações cujos sentidos variam de acordo com os sistemas de valores dos atores envolvidos. Valemo-nos, para efeito deste estudo, de pesquisa junto a bibliografia especializada, tendo sido utilizada a análise de conteúdo, propriamente dita.

O artigo está divido em cinco partes: na primeira parte propomos uma discussão sobre a inserção do Brasil no Sistema da Cooperação Internacional para o Desenvolvimento, salientando a dualidade de sua atuação como "receptor" e "doador" no âmbito da cooperação; na segunda parte fazemos uma abordagem acerca da política externa brasileira e da cooperação internacional para o desenvolvimento durante os dois governos do presidente "Lula da Silva"; na terceira parte tratamos particularmente das estratégias de cooperação Sul-Sul, empreendidas durante o governo Lula; em seguida, na quarta parte, apresentamos algumas percepções críticas sobre a cooperação internacional do Brasil para o 
Eixo Sul na chamada "Era Lula"; na quinta e última parte, tecemos as considerações finais do percurso aqui cumprido.

\section{A INSERÇÃO DUAL DO BRASIL NO SISTEMA DA COOPERAÇÃO INTERNACIONAL PARA O DESENVOLVIMENTO}

A inserção política do Brasil como país em desenvolvimento no sistema de cooperação internacional remonta aos anos 1930, época na qual figurava, especificamente, como um país receptor de cooperação técnica, em um contexto marcado pela série de transformações de caráter cultural, social e político pelas quais passava o país (GONÇALVES, 2011, p. 43). No entanto, foi somente a partir dos anos 1950, quando firmou diferentes acordos internacionais e criou o primeiro órgão de coordenação da cooperação técnica no país, a Comissão Nacional de Assistência Técnica (CNAT), que a cooperação técnica ${ }^{4}$ no Brasil ganhou mais visibilidade (BARBOSA, 2011; CORRÊA, 2011; GONÇALVES, 2011). Entre os anos 1960 e 1970, com os movimentos de independência de ex-colônias africanas e asiáticas e de países não alinhados e com as crescentes articulações no âmbito da ONU, esta cooperação ganhou "corpo" fazendo com que as iniciativas brasileiras caminhassem "a reboque" do início das atividades da cooperação técnica internacional, que apareceram motivadas pelas Nações Unidas em função da necessidade de reconstruir os países afetados pela Segunda Guerra Mundial e de acelerar o desenvolvimento dos chamados "países em desenvolvimento" (BARBOSA, 2011, p. 19-20).

Ao dividir a atuação do Brasil na cooperação internacional, Corrêa (2011) indica três diferentes períodos. As quatro primeiras décadas, que se referem ao período entre 1950 e fins da década de 1980, representam o típico modelo de cooperação Norte-Sul praticado em diversas regiões do mundo à época, configurando-se como uma cooperação marcada por um viés economicista, com a fomentação de programas e projetos com vistas ao fortalecimento

4 Segundo Barbosa (2011, p. 19-20), em 1959, a Assembleia Geral da ONU reviu o então vigente conceito de "assistência técnica", substituindo-o por "cooperação técnica", termo considerado mais propício para definir uma relação que, se, por um lado, pressupunha a existência de partes desiguais, por outro, representava uma relação de trocas, de interesses mútuos entre as partes. 
de instituições promotoras do crescimento econômico do país. Pauta-se, aí, a crença no crescimento econômico como elemento impulsionador da melhoria das condições de vida da sociedade. $O$ segundo período, que se refere a desde meados da década de 1980 até o ano de 2005, aproximadamente, abarca a redemocratização do Brasil e o engajamento em temas da agenda internacional relacionados ao desenvolvimento. Já o terceiro período citado pelo autor engloba a primeira década dos anos 2000, que corresponderia a um novo ciclo de cooperação entre instituições brasileiras e seus parceiros bilaterais e multilaterais, contemplando a "sistematização de boas práticas para fins de sua disseminação a outros países em desenvolvimento", característica da atuação brasileira na cooperação internacional para o desenvolvimento, em especial na sua vertente Sul-Sul (CORRÊA, 2011, p. 14-16), no governo do presidente Lula.

Houve, nessa perspectiva, ao longo dos anos, um adensamento da cooperação no Brasil, tanto do ponto de vista conceitual quanto como prática política propriamente dita. No entanto, conforme enfatiza Cordeiro (2012, p. 147), na linguagem diplomática e política, o termo "cooperação" carregou fortemente e por longo tempo, no país, uma lógica essencialmente desenvolvimentista. Em termos de elaboração do conceito brasileiro de cooperação, Cervo (1994) ressalta que este, historicamente, se baseou em três categorias de elementos que remetem a seu "significado político", seus "fins econômicos" e seu modus faciendi. No que concerne ao seu "significado político", a cooperação era utilizada para refletir, de forma sintética, a essência da política exterior, realçando o seu caráter pacifista e não confrontacionista que a legitimariam, portanto, diante da nação e da comunidade internacional, com vistas à promoção da união do Terceiro Mundo na busca por firmar uma liderança nesta área. No que diz respeito aos "fins econômicos", sustenta-se que a cooperação era procurada em razão do suporte dos insumos externos, tais como empresas, capitais e tecnologias, fundamentais para a realização das metas do desenvolvimento. Nesta perspectiva, buscava-se não apenas superar o subdesenvolvimento, mas atingir o pleno desenvolvimento. A terceira e última categoria trata da conduta brasileira na captação e implementação da cooperação internacional caracterizada pelo pragmatismo da sua política exterior. Neste sentido, a "cooperação pragmática" seria uma espécie de "cooperação 
desideologizada", buscando explorar oportunidades de forma realista e criando "alternativas diante de obstáculos" (CERVO, 1994, p. 41-42).

Sobre esse último aspecto, entretanto, permitimo-nos discordar de Cervo (1994), uma vez que não acreditamos na possibilidade de uma desconexão entre a cooperação internacional e a política. Entendemos que, mesmo em um esforço de atuação pragmática, ainda assim, a dimensão político-ideológica nunca esteve deslocada da lógica de atuação do Brasil no âmbito da cooperação internacional. Ao contrário, esta sempre teve que lidar com interesses, conflitos e relações de poder relacionados, por sua vez, a questões de ordens política e ideológica.

Entre os anos 1960 e os anos 1970, com os recursos provenientes da cooperação internacional, o Brasil pôde maximizar os conhecimentos recebidos e adaptá-los à sua realidade. Houve, nesta perspectiva, uma reestruturação das instituições responsáveis pelo desenvolvimento nacional e a emergência dos primeiros acordos nos quais o país figurou como prestador de cooperação técnica internacional. Neste sentido, enfatiza Ayllón Pino (2010, p. 2), a origem da participação do Brasil enquanto ator da CID remonta, em especial, à década de 1970, com a incorporação no Plano de Ação de Buenos Aires e da sua experiência enquanto receptor da ajuda internacional. Já existia, aí, a percepção de que o país havia conseguido maximizar a absorção dos benefícios provenientes da ajuda recebida dos países do Eixo Norte por meio da CID. Constituía, portanto, neste momento, uma espécie de "obrigação moral" do país se solidarizar com os países menos desenvolvidos, incentivando-os e dando-lhes apoio, em uma perspectiva de dar um retorno dos seus benefícios e aprendizados em prol do desenvolvimento. Esta década, no Brasil, é marcada pela estruturação de um programa de cooperação internacional a ser prestada pelo país ao exterior como resposta aos benefícios recebidos pela transferência de conhecimentos oriundos de países mais avançados, o que, além de contribuir para o esforço de desenvolvimento nacional, o tornava capaz de prestar cooperação para outros países em desenvolvimento. Deu-se, neste contexto, portanto, a inserção do país em inúmeros projetos de cooperação prestada para países do Eixo Sul, impulsionada, vis a vis, por uma política de maior aproximação com países em desenvolvimento e pela demanda externa crescente pela 
cooperação brasileira (CERVO, 1994, p. 49), o que começou a imprimir no país, o seu duplo papel na cooperação técnica internacional, de receptor da cooperação proveniente do Norte e socializador de experiências e conhecimentos para o Sul (AYLLÓN PINO; LEITE, 2010).

É a partir daí que a temática da cooperação com países em desenvolvimento ganhou destaque na agenda diplomática brasileira, segundo Gonçalves (2011, p. 46), que aponta, nesta perspectiva, o aumento significativo de iniciativas de cooperação técnica prestadas a partir deste período. De acordo com Cervo (1994, p. 49), com a determinação da Conferência de Buenos Aires de que o Programa das Nações Unidas para o Desenvolvimento (PNUD) organizasse e apoiasse a Cooperação Técnica para o Desenvolvimento (CTPD), o interesse dos países do "Terceiro Mundo" pela cooperação técnica internacional (CTI) brasileira foi despertado. Sobre isto, no entanto, afirma que a credibilidade e a confiança foram condicionantes do interesse e da demanda. De fato, o prestígio crescente adquirido pelo país em função da sua trajetória de desenvolvimento findou por aumentar a demanda de países do Sul pelos seus conhecimentos técnicos e experiências empreendidas, o que foi consolidando o Brasil na posição de "prestador" de cooperação.

Entre o final dos anos 1970 e início dos anos 1980, teve início uma nova fase da CTI no Brasil, fortalecida pela sua inserção racional na política externa, pela remontagem do sistema nacional de cooperação técnica e pela implantação de agências internas melhor preparadas em termos de recursos humanos e equipamentos para cooperar, dentre outras. A segunda metade da década de 80 foi marcada, por sua vez, pela criação da Agência Brasileira de Cooperação ( $A B C$ ), em setembro de 1987, que passou a centralizar as ações políticas e técnicas do sistema brasileiro de cooperação técnica internacional. Vinculada ao Ministério das Relações Exteriores e com a atribuição da formulação de políticas específicas de gerenciamento e controle de convênios entre países doadores e órgãos e organizações executoras no Brasil, a $A B C$, não obstante a importância da sua criação, já nasceu sofrendo uma espécie de "crise de identidade", na ambiguidade de um país tradicionalmente receptor de CNS, buscando ser doador de cooperação Sul-Sul. À ABC coube, desde então, a responsabilidade administrativa por ambos os aspectos desta relação (CERVO, 1994, p. 53). 
O esgotamento do modelo de cooperação internacional recebido e o avanço do conhecimento técnico do Brasil marcaram os anos 1980 e o país, efetivamente, modificou o seu perfil, compatibilizando os papéis de "receptor" e "doador" de ajuda a países em desenvolvimento, o que coadunou com a intenção de ampliação e fortalecimento de seus interesses internacionais (AYLLÓN PINO, 2010, p. 2). Nesta perspectiva, a cooperação internacional oferecida pelo Brasil se constituiu como instrumento da sua política externa, propiciando que o país fortalecesse a sua presença internacional por meio da cooperação, passando, neste ínterim, a ser classificado pela OCDE como um dos "doadores emergentes" da CID, como "país de renda média" (PRM), conforme classifica Hirst ${ }^{5}$ (2009; 2010), que, afirma, tem como características a capacidade de ampliação da cooperação horizontal sem que, no entanto, abram mão da sua condição de receptor de cooperação. Estes chamados "países de renda média", em cujo grupo passou a figurar o Brasil, combinariam, portanto, a condição de "doador" e de "receptor" na estrutura da cooperação internacional para o desenvolvimento.

\section{A POLÍTICA EXTERNA BRASILEIRA E COOPERAÇÃO INTERNACIONAL PARA O DESENVOLVIMENTO NO GOVERNO “LULA DA SILVA"}

É na primeira década do século XXI, após um longo período de alinhamento quase automático (FIORI, 2013) do país às "grandes potências ocidentais", que o Brasil, sob a liderança do então presidente da república Luiz Inácio "Lula" da Silva, se propõe a aumentar sua autonomia internacional, elevando a capacidade de defesa de suas posições em virtude de seu poder político, econômico e militar. Conforme relata Almeida (2019), no campo da política externa, o programa proposto pela coalizão encabeçada pelo Partido dos Trabalhadores (PT) - responsável pela eleição de Lula - previa uma atuação mais assertiva, na qual a associação da política externa como meio para implantação de uma política de

Apesar de utilizar o termo, a autora questiona o uso da categoria PRM para abordar a $\mathrm{Cl}$, alertando sobre o risco desta utilização, em especial quando se trata dos chamados "doadores emergentes". 
desenvolvimento nacional foi claramente estabelecida. No referido programa ganharam destaque, além da questão do desenvolvimento, fatores como: integração regional no âmbito da América do Sul; reconstrução do MERCOSUL; negociação relacionada às medidas protecionistas dos EUA para a criação da Área de Livre Comércio das Américas (ALCA); estabelecimento de relações equilibradas com os países desenvolvidos; aproximação com países de importância regional, como África do Sul, Índia, China e Rússia, e também do continente africano de modo geral, que possibilitassem construir relações mais democráticas nos organismos multilaterais (ALMEIDA, 2019, p. 44 e 45).

Cabe salientar, nesta perspectiva, a relação intrínseca entre a figura do então presidente, a sua ideia de política externa e os caminhos seguidos pelo país, neste âmbito. Assim, sob a liderança do Presidente Lula, o Brasil se projetou internacionalmente, com grande força, pleiteando um lugar de liderança na América Latina, especificamente, e no chamado Eixo Sul, de um modo geral. Para Fiori (2013), esta liderança presidencial permitiu que o país caminhasse na direção de uma nova estratégia internacional, tomando posições, estabelecendo alianças e criando expectativas dentro do jogo de poder mundial (FIORI, 2013, p. 31-32).

Neste sentido, corrobora Ayllón Pino (2010) lembrando que a expansão da cooperação ofertada pelo Brasil se deu a partir de 2003, com a sua ascensão econômica e a chegada de Lula ao poder, quando o governo brasileiro executou uma ampla reestruturação da sua política exterior, priorizando a CSS. Emerge daí o conceito de "diplomacia solidária" adotado pelo Brasil, que colocou à disposição de outros países em desenvolvimento as experiências e conhecimentos de instituições nacionais especializadas, sem condicionantes, de acordo com as suas demandas e respeitando a sua soberania. Houve, a partir de então, um crescimento do país perante a comunidade internacional, tornando-o membro de um grupo de países que faziam parte do "caleidoscópio central" do sistema, conforme relata Fiori:

[...] Brasil ingressou no rol dos estados e das economias nacionais que fazem parte do 'caleidoscópio central' do sistema, onde todos competem com todos e todas as alianças são possíveis, em função dos objetivos estratégicos de cada país e de sua proposta de mudança do sistema internacional (FIORI, 2013, p. 34). 
Ao tratar dessa "virada" na atuação do Brasil, que projetou internacionalmente o país a partir do Governo Lula, se faz necessário reconhecer o papel e a importância do então Ministro das Relações Exteriores, Celso Amorim ${ }^{6}$, no que tange à CSS, de um modo geral, e, em especial, no que se refere à criação do Fórum IBAS - reunindo Índia, Brasil e África do Sul - e a condução da relação do Brasil com o continente africano. Sob a sua gestão, o Brasil construiu a ideia de maior autonomia da sua política externa que, conforme o próprio Amorim ${ }^{7}$ deixou de ser "excessivamente domesticada e facilmente domesticável".

Do ponto de vista quantitativo, no que se refere à participação do Brasil na condição de "doador" na cooperação para o desenvolvimento internacional, dados apontam para um significativo crescimento. Segundo o relatório resultante da pesquisa sobre a "Cooperação Brasileira para o Desenvolvimento Internacional: 2005-2009” (2010), realizada pela Agência Brasileira de Cooperação ( $A B C)$, em parceria com o Instituto de Pesquisa Econômica Aplicada (IPEA), o total dos recursos investidos pelo país na cooperação para o desenvolvimento internacional nesse período foi de $\mathrm{R} \$ 2.898 .526 .873,49$ - ou cerca de US\$1,43 bilhão -, dividido entre as modalidades de ajuda humanitária, bolsa de estudo para estrangeiro, cooperação técnica, científica e tecnológica e as contribuições para organizações internacionais. A metodologia utilizada não incluiu, no entanto, recursos investidos no perdão e renegociação de dívida, nos projetos de cooperação realizados por universidades públicas (federais e estaduais) e nos empréstimos concessionais (com taxas de juros diferenciadas e percentual de doação), que são três vertentes de ajuda consideradas pela Ajuda Oficial para o Desenvolvimento (AOD). Deste modo, para construir uma comparação entre o apoio fornecido pelo Brasil e a ajuda recebida de países e agências multilaterais (entre 2005 e 2009, o Brasil recebeu US\$ 1,48 bilhão), o Le Monde Diplomatique Brasil ${ }^{8}$ (2011) fez um cruzamento de dados somando, ao valor disponibilizado pelo IPEA/ABC, o montante total que o Brasil forneceu em perdão de dívida no mesmo período (US\$ 448 milhões), obtendo um valor total

6 O diplomata Celso Luiz Nunes Amorim foi Ministro de Relações Exteriores do Brasil entre os anos 1993 e 1995, no governo do então presidente Itamar Franco. De 2003 a 2010, foi novamente Ministro das Relações Exteriores, desta vez no governo Lula.

7 Discurso proferido pelo chanceler Celso Amorim na Conferência "2003 - 2013: uma nova política externa”, realizada em julho de 2013, em São Bernardo do Campo.

$8 \quad$ Publicado em abril de 2011. 
de US\$ 1,88 bilhão $^{9}$. Assim, quantitativamente, a partir deste momento histórico, o Brasil passou a figurar como um país mais "doador" do que "receptor" de recursos, no cenário da cooperação internacional.

Se, durante um longo período, o país foi basicamente "receptor" de ajuda internacional, apresentou no governo do presidente Lula, uma ampla gama de ações e projetos de cooperação internacional com países em desenvolvimento e, conforme indicou o Le Monde Diplomatique (2011), deixou de receber recursos de alguns fundos como, por exemplo, o Banco Mundial e o Fundo Monetário Internacional (FMI), para os quais passou a enviar dinheiro. No entanto, isto não significa que o Brasil tenha deixado de receber recursos da cooperação. O país seguiu recebendo ajuda de outros países e de agências multilaterais, o que lhe conferiu, de fato, o duplo papel de "receptor" e de "doador", na lógica da cooperação.

Todas essas mudanças operadas na cooperação internacional para o desenvolvimento, fruto, não somente, mas, especialmente, das transformações político-econômicas ocorridas no mundo aliadas à sua própria reconfiguração político-econômica colocaram o Brasil em outro lugar, no âmbito da cooperação internacional. Um país que avançava na busca da projeção de sua influência para além das fronteiras nacionais procurando assumir um papel de liderança junto a países periféricos do sistema internacional com os quais dialogava e construía cada vez mais alianças, tendo como um dos caminhos eleitos a lógica da cooperação. Neste sentido, buscava uma alternativa ao modelo tradicional da cooperação internacional que, historicamente, dividiu os seus atores partícipes em dois grupos: os países desenvolvidos, como doadores de ajuda e/ou cooperação; e os países em desenvolvimento, como seus beneficiários ou receptores, em um formato verticalizado característico da cooperação NorteSul, cujo modelo chegou a um esgotamento na virada do milênio. Neste novo lugar, mesmo não estando entre os maiores doadores de recursos financeiros, despontou um Brasil protagonista da chamada cooperação Sul-Sul ou como a classificava o governo brasileiro da época, da "cooperação horizontal", uma cooperação fundada em outras bases e princípios que não aqueles da cooperação tradicional.

9 Dados do Ministério da Fazenda, obtidos através do Le Monde Diplomatique Brasil. 


\section{O GOVERNO LULA E SUAS ESTRATÉGIAS DE COOPERAÇÃO SUL-SUL PARA O DESENVOLVIMENTO}

Após o período de redemocratização, o Brasil iniciou a sua busca por se tornar um "player internacional" cada vez mais reconhecido como um "player autônomo", fora do antigo campo ideológico que existia na época da Guerra Fria, na busca por um espaço na arena internacional. A partir da década de 1990, com o fortalecimento e a consolidação de muitas instituições brasileiras, o país desenvolveu tecnologias de ponta no campo social, dando início, em seguida, a um processo de divulgação das suas boas práticas, no intuito de se mostrar como um país sério com grande potencial de desenvolvimento e um capital humano especializado. Passou, assim, a ser chamado, cada vez mais, a atuar como país prestador de cooperação, sobretudo em uma perspectiva de socializar a expertise obtida em diversas áreas, em especial no que tange às chamadas tecnologias sociais que começaram a ser exportadas para os países da região como "um novo modelo de políticas sociais". Firmou-se, deste modo, no Brasil, a perspectiva da cooperação Sul-Sul baseada fortemente nas tecnologias, conhecimentos e técnicas desenvolvidas pelo país cuja possibilidade de socialização com base nos aprendizados obtidos se tornou foco primordial da sua atuação no âmbito da cooperação internacional.

O rearranjo em termos de potências emergentes - decorrente, por um lado, da diminuição do poder econômico norte-americano e, por outro, do próprio declínio europeu possibilitou que novos atores passassem a ocupar espaço no cenário internacional, trazendo consigo outras formas de cooperação e visibilizando outras lógicas de atuação no âmbito da cooperação internacional para o desenvolvimento. Deste modo, é inegável que tanto o Brasil como a cooperação Sul-Sul foram postos em evidência neste contexto. No entanto, a CSS não pode ser considerada uma inovação na política externa brasileira, uma vez que, desde a 
década de 1970, o país atua no marco deste tipo de cooperação como prestador de cooperação para países do Sul, antes mesmo de a ONU institucionalizar a CTPD ${ }^{10}$.

No governo do Presidente Fernando Henrique Cardoso (1995-2002), a CSS já havia assumido uma maior relevância na agenda da política externa. No entanto, foi, em especial, a partir do "Governo Lula" que o Brasil consagrou, completamente, o seu status de país emergente e obteve visibilidade, não somente pelo seu crescimento econômico, mas, também, pelo alcance e resultados obtidos através da execução dos seus projetos sociais. A chegada ao poder do Presidente Luiz Inácio "Lula" da Silva, em 2003, marcou a expansão brasileira no âmbito da cooperação internacional, com o governo brasileiro começando a executar uma ampla reestruturação da sua cooperação ao exterior destinada a priorizar, a partir de então, a CSS (AYLLÓN PINO, 2010, p. 2) e dando a esta modalidade de cooperação enorme destaque. Assim, desde meados da década de 1990 e, sobretudo, a partir e durante o Governo Lula, a CSS ganhou protagonismo inédito na atuação externa do Brasil.

Com o empenho do então Presidente Lula em colocar o Brasil em outro lugar no cenário internacional e com o êxito de políticas emblemáticas, o país começou a chamar a atenção do mundo - que vivenciava um momento histórico de falta de alternativas ideológicas, políticas e econômicas em função da crise -, e virou uma espécie de popstar, começando a ter cada vez mais espaço e influência internacional, provocando, por sua vez, em outros países, uma busca significativa pela experiência brasileira. Iniciou-se, deste modo, no Brasil, uma política proativa de cooperação com o Eixo Sul, formulada nos marcos de uma política externa que se destacava como "ativa e altiva"11, com vistas a ampliar a projeção do país no cenário internacional (LESSA et al., 2012, p. 95). Nesta perspectiva:

A partir de 2004, a cooperação brasileira com países em desenvolvimento foi significativamente ampliada, pautando-se desde então pelas seguintes diretrizes:

10 A cooperação técnica internacional foi inicialmente conhecida como assistência técnica internacional, conforme a Resolução 200, da Assembleia Geral da Organização das Nações Unidas (AG/ONU) de 1948, que trata da "assistência técnica para o desenvolvimento econômico", tendo sido, onze anos depois, o termo assistência substituído formalmente pelo termo cooperação na AG/ONU através da Resolução 1383, de 1959. (LOPES, 2011).

11 Segundo Velasco e Cruz (2013), essa política "ativa e altiva" tinha - e tem - como horizonte estratégico a construção de um polo de poder em um mundo em transição. 
priorizar programas de cooperação técnica que favoreçam a intensificação das relações do Brasil com seus parceiros de maior interesse para a política exterior brasileira; apoiar projetos vinculados sobretudo a programas e prioridades nacionais de desenvolvimento dos países recipiendários; canalizar os esforços de CGPD para projetos de maior repercussão e âmbito de influência, com efeito multiplicador mais intenso; privilegiar projetos com maior alcance de resultados; apoiar, sempre que possível, projetos com contrapartida nacional e/ou com participação efetiva de instituições parceiras e estabelecer parcerias preferencialmente com instituições genuinamente nacionais (MRE, 2008). (BUSS; FERREIRA, 2012, p. 253).

A ampliação da atuação brasileira no âmbito da cooperação internacional pode ser percebida na expressão dos seus resultados quantitativos. De acordo com a pesquisa do IPEA/ABC (2010), a ajuda prestada aos países em desenvolvimento pelo Brasil aumentou $50 \%$ em termos reais, de 2005 a 2009, sendo os maiores investimentos relativos a contribuições para organismos internacionais (76\% do total), bolsas de estudo para estrangeiros $(10 \%)$ e a assistência humanitária, prestada em casos de desastres naturais ou conflitos, a vertente de cooperação que mais cresceu (aumento de 73 vezes). Os recursos investidos pelo governo na Cooperação Brasileira para o Desenvolvimento Internacional (COBRADI), em 2010, totalizaram um montante de R\$ 1.625.141.181 (ou cerca de U\$ 923.375.671), cuja consolidação por modalidade consta no Quadro 1 abaixo.

Quadro 1 - Gastos com a Cooperação Brasileira para o Desenvolvimento Internacional (Cobradi), por modalidade - Brasil, 2010

\begin{tabular}{|l|c|c|c|}
\hline MODALIDADE & \multicolumn{1}{|c|}{$\begin{array}{c}\text { TOTAL } \\
\text { (R\$) }\end{array}$} & $\begin{array}{c}\text { TOTAL } \\
\text { (US\$) }\end{array}$ & PROPORÇÃO (\%) \\
\hline Cooperação técnica & 101.676 .174 & 57.770 .554 & 6,3 \\
Cooperação científica e tecnológica & 42.255 .987 & 24.009 .084 & 2,6 \\
Cooperação educacional & 62.557 .615 & 35.544 .099 & 3,8 \\
Cooperação humanitária & 284.186 .759 & 161.469 .749 & 17,5 \\
Apoio e proteção a refugiados & 1.039 .225 & 590.469 & 0,1 \\
Operações de manutenção da paz & 585.063 .470 & 332.422 .426 & 36,0 \\
Gastos com organismos internacionais & 548.361 .950 & 311.569 .290 & 33,7 \\
Total (Cobradi) & 1.625 .141 .181 & 923.375 .671 & 100,0 \\
\hline
\end{tabular}

Fonte: Ipea 
Porém, mesmo levando em conta o crescimento dos recursos aplicados entre 2005 e 2009 e o montante investido em 2010, os valores ainda podem ser considerados pequenos, em especial se comparados aos montantes dos doadores da OCDE que têm como meta a doação de $0,7 \%$ do PIB por ano para AOD. Nesta perspectiva, conforme salientou Cordeiro (2012, p. 148), para alcançar os $0,7 \%$ da AOD/OCDE, a cooperação brasileira teria de ser 41 vezes maior do que, de fato, o foi neste período. No entanto, os dados refletem, inegavelmente, o crescimento da economia brasileira, o desejo do país de obter maior influência nas decisões mundiais - vide as ambições brasileiras por um assento permanente no Conselho de Segurança da ONU - e a busca por um papel de protagonismo do Brasil no tabuleiro das relações internacionais, neste período.

Importa salientar que o entendimento do Brasil acerca da sua cooperação Sul-Sul oficial se refere, especificamente, à CTPD, excluindo deste âmbito as transferências financeiras voltadas para a promoção comercial - como os empréstimos realizados pelo Banco de Desenvolvimento Econômico e Social (BNDES) a outros países em desenvolvimento - e doações que não estejam diretamente ligadas à promoção do desenvolvimento dos beneficiários, como a assistência humanitária, por exemplo (AYLLÓN PINO; LEITE, 2009), constando, inclusive, nos documentos e informes ${ }^{12}$ da $A B C$, como sinônimo de Cooperação Horizontal e de Cooperação Técnica para o Desenvolvimento. Valorizou-se, desse modo, nos programas de cooperação implementados, a transferência de "conhecimentos, experiências de sucesso e sofisticados equipamentos", que ajudassem na promoção do desenvolvimento sustentável e contribuíssem para o desenvolvimento social dos países.

Parte constitutiva da cooperação técnica brasileira, a socialização da expertise no âmbito da cooperação refletia os avanços do país no que tange à produção e implantação de novas tecnologias, em especial as que diziam respeito à área social. Segundo o IPEA/ABC (2010, p. 32), o Brasil reunia acervo de "tecnologias, conhecimentos, técnicas e experiências testadas e validadas" que estavam aptas "para serem compartilhadas com outras nações", fruto de investimentos em "instituições e em indivíduos situados em contextos, por vezes, de

12 Coordenação Geral de Cooperação Técnica entre Países em Desenvolvimento (CGPD). Disponível em: <http://www.abc.gov.br/abc/coordenacoesCGPDIntroducao.asp>. 
significativas carências materiais e de capital humano". A superação dessas carências, por sua vez, constituiu-se em elemento impulsionador para que o país pudesse alcançar uma posição relevante no cenário internacional de Cooperação Técnica, Científica e Tecnológica (CTC\&T). Assim, de país marcado pelas imensas desigualdades sociais a produtor de inovações de significativo impacto social, o Brasil, passou a ser visto como exemplo inspirador para muitos países em desenvolvimento que acreditavam na viabilidade - em função das similaridades históricas, sociais, culturais - de implantação das tecnologias brasileiras nos seus territórios.

Importa, contudo, na perspectiva da cooperação técnica ofertada e recebida, que se desconstrua a ideia de que a proximidade de condições estruturais entre os países do Sul sejam determinantes de uma eficácia maior dos modelos exportados. Conforme salientou Leite (2012, p. 24-25), mesmo que "os problemas que atingem os países em desenvolvimento sejam similares, as oportunidades e desafios à mudança política são particulares, ligados a ideologias, lobbies e aparatos burocráticos específicos". Deste modo, não necessariamente, uma iniciativa bem-sucedida em um país do Sul terá os mesmos impactos em outro país (LEITE, 2012, p. 24-25). Deste modo, ainda que existam vantagens para que dois países com trajetórias políticas, culturais e sociais semelhantes estabeleçam relações de parceria entre si, somente isto não garante a efetiva promoção de um desenvolvimento sustentável dos pontos de vista econômico, político e social (INSTITUTO DE ESTUDOS SOCIOECONÔMICOS; CHRISTIAN AID, 2012, p. 25).

A cooperação técnica brasileira com outros países em desenvolvimento era regida, segundo o discurso oficial da época, por alguns princípios basilares que determinavam a atuação do país, como: a diplomacia solidária; a atuação em resposta a demandas de países em desenvolvimento (demand-driven); o reconhecimento da experiência local; a não imposição de condicionalidades; a não vinculação a interesses comerciais ou fins lucrativos; e a não ingerência em assuntos internos dos países parceiros (LEITE; SUYAMA; WAISBICH, 2013, p. 1). Alguns aspectos da cooperação brasileira eram repetidamente enfatizados pelos representantes do governo e em documentos oficiais ${ }^{13}$ como determinantes deste modelo de

13 Vide relatórios elaborados pelo IPEA e pela ABC (2010; 2016). 
cooperação e, dentre eles, se destacavam o respeito à autonomia e à soberania dos países cooperados. Neste sentido, importa observar, mais uma vez, que a Cooperação Brasileira para o Desenvolvimento Internacional estava posta no discurso oficial como "cooperação horizontal do Brasil para o desenvolvimento", enfatizando, assim, a ideia de horizontalidade das relações estabelecidas.

Somava-se a esses princípios outro aspecto relevante da cooperação do país, que dizia respeito ao fato de a totalidade dos recursos investidos pelo governo federal brasileiro, "no governo de outros países, em nacionais de outros países em território brasileiro, ou em organizações internacionais com o propósito de contribuir para o desenvolvimento internacional" (INSTITUTO DE PESQUISA ECONÔMICA APLICADA; AGÊNCIA BRASILEIRA DE COOPERAÇÃO, 2010, p. 17), ser totalmente a fundo perdido, o que distanciava a CSS brasileira, conforme relatam Milani e Carvalho (2012, p. 15), do conceito de ajuda oficial ao desenvolvimento da OCDE e, consequentemente, do modelo tradicional de ajuda internacional prestada pelas nações doadoras do Hemisfério Norte.

Segundo o ministro Farani ${ }^{14}$, ex-diretor geral da $A B C$, a diretriz central da cooperação Sul-Sul brasileira do período se apoiava no histórico de soluções pacíficas da diplomacia no país, podendo ser descrita como uma "cooperação horizontal, fundada nos princípios da solidariedade, sem condicionalidades, sem pacotes de oferta pré-estabelecido", mas que buscava o "desenvolvimento e a adaptação dos projetos de cooperação a partir das realidades dos países demandantes" (CORDEIRO, 2012, p. 150).

Diferente dos doadores tradicionais que, com muita frequência, trazem embutidas, nas suas ações de cooperação, condicionalidades de distintas ordens, a não imposição de condicionalidades era apresentada como importante diferencial do Brasil no âmbito da sua cooperação, denotando, em alguma medida, um caráter desinteressado da cooperação brasileira ou um interesse localizado na projeção do país no cenário internacional, mas destituído da ideia de ganhos comerciais ou econômicos e financeiros diretos.

14 Em entrevista concedida a Rui Mesquita Cordeiro (2012, p. 150). 
Segundo o IPEA e a ABC (2010, p. 32-33), o objetivo último do Brasil no âmbito da sua cooperação técnica, no período, consistia no "desenvolvimento integral dos parceiros, que impulsione mudanças estruturais em suas economias, levando a um crescimento sustentável que garanta, igualmente, inclusão social e respeito ao meio ambiente". O Brasil atuava, portanto, sob a ideia de uma espécie de construção de parcerias para o desenvolvimento, cedendo conhecimento para quem precisava e somente junto àqueles que solicitavam a sua presença. Nesta perspectiva, agia exclusivamente por demand driven, ou seja, atendendo aquilo que the era demandado pelos países parceiros, buscando adaptar suas experiências de desenvolvimento às realidades e capacidades locais, elemento fundamental para a viabilidade destas iniciativas.

Conforme Candeas (2012, p. 182), ao atuar na perspectiva de demand-driven, o Brasil definiu o seu estilo de cooperação diferenciando-se da cooperação realizada pelos países desenvolvidos cuja cooperação técnica se baseia "mais na capacidade de oferta de suas agências (supply-driven) do que nas necessidades efetivas dos países receptores". Neste sentido, as "soluções" apresentadas, muitas vezes atendiam mais aos "interesses e mecanismos institucionais dos países doadores" - sejam esses interesses comerciais, de agências de consultoria, ou a cálculos de influência político-estratégica (tied aid ${ }^{15}$ ) -, do que às reais necessidades de desenvolvimento do país receptor, o que teria determinado a relativa ineficácia das políticas de cooperação técnica tradicionais, apesar do importante volume de recursos investidos pelas agências de cooperação. Assim, o mundo desenvolvido não teria sido capaz de produzir transformações estruturais no Estado e na sociedade dos países receptores (CANDEAS, 2012, p. 182).

A opção pela atuação a partir do que era demandado pelo país parceiro vinha acompanhada pela lógica da não interferência e do respeito à autonomia e à soberania dos Estados. Nesse contexto, o Brasil desenvolvia um estilo de cooperação voltado para reformas estruturantes que estimulassem as autoridades locais a pensar as necessidades estratégicas

15 O termo tied aid, que definimos livremente como "ajuda ligada", faz referência à ajuda disponibilizada pelos países sob a condição de que parte seja utilizada para a compra de bens ou serviços do país doador. Seria, neste caso, uma ajuda condicionada. 
do país e a elaborar projetos de desenvolvimento a partir de uma perspectiva endógena, inspirando-se na experiência brasileira. Deste modo, agentes governamentais estrangeiros realizavam visitas para conhecer programas, políticas e melhores práticas no Brasil, e técnicos brasileiros eram enviados aos países para auxiliarem na elaboração de programas nacionais (CANDEAS, 2012, p. 182). Havia ênfase no respeito e no reconhecimento das experiências locais, no entanto, não existia um plano de atuação no longo prazo, uma vez que a CSS brasileira era feita como resposta à variada e crescente demanda recebida. De acordo com a Cepal (2010), este modelo de CSS do Brasil era diferenciado e declaradamente solidário, altruísta e desprovido de outros interesses não explícitos.

Essas características da cooperação brasileira, constantemente ressaltadas nos discursos e documentos oficiais, no entanto, não estão isentas de serem postas em discussão e vistas sob o prisma da análise crítica, ainda que haja um entendimento majoritário de que grande parte das bases postas como sustentáculos desta cooperação pareçam de fato reais e a diferenciem da cooperação tradicional Norte-Sul. Ainda assim, relações de poder são sugeridas como algo inerente ao "jogo da política externa" do qual a cooperação é parte constitutiva. Cumpre registrar, portanto, que, apesar de ter proposto um novo formato para a cooperação internacional, a cooperação brasileira deste período não apresentou, necessariamente, resultados que possam qualificá-la como mais eficaz.

Em termos de atuação geográfica, o Brasil se propôs a atuar irrestritamente com os países que demandavam a sua cooperação, no entanto, em especial no período correspondente ao primeiro mandato do Presidente Lula, houve um fortalecimento ou uma espécie de consolidação das relações com os parceiros tradicionais da cooperação brasileira: os países do Mercosul, os países sul-americanos e a África lusófona. Neste sentido, podemos perceber, inicialmente, na estrutura da CTPD brasileira, alguns níveis de prioridade, que foram, porém, expandidas a partir do segundo mandato do Presidente Lula, coadunando com a expansão da rede de embaixadas brasileiras e a postura do país Brasil junto ao G20, ao fórum IBAS, e ao BRICS. Nessa perspectiva, o Brasil passou a se colocar como interlocutor não só dos parceiros tradicionais, passando a buscar investidores e ações de cooperação no mundo 
inteiro, ampliando a sua prioridade geográfica e desenvolvendo cooperação com a Ásia, com países do leste europeu e do leste asiático, dando a eles, também, uma relevância.

Do ponto de vista da sua gestão, a cooperação técnica para o desenvolvimento do Brasil, focada nos países do Eixo Sul, estava formalmente abrigada na $\mathrm{ABC}^{16}$ que, por sua vez, é vinculada ao MRE. Cabia, deste modo, à $A B C$ coordenar a cooperação técnica recebida e prestada pelo Brasil, regulada pelos Acordos Básicos de Cooperação e sujeita à aprovação legislativa e por Ajustes Complementares e Documentos de Projetos. Importa registrar, no entanto, que a inexistência de um marco legal referente à prestação de cooperação técnica implicava que os projetos e as ações de cooperação se concretizassem por meio de arranjos com organismos internacionais, principalmente o Programa das Nações Unidas para o Desenvolvimento. Não obstante o lugar da $A B C$ na CTPD do Brasil, releva-se a existência de ações de cooperação de outras ordens, oriundas de diferentes instâncias do Estado, que provocavam um crescente entrelaçamento da CTPD brasileira com outras modalidades de cooperação e com outras instituições nacionais, que passaram a se configurar como protagonistas na definição de prioridades e de abordagens referentes à cooperação, criando um horizonte de limitações à $A B C / M R E$ no tocante à definição de agendas (LEITE; SUYAMA; WAISBICH, 2013).

No que tange às questões orçamentárias, houve um incremento do orçamento da $A B C$ até 2010 , seguido por uma redução drástica de cerca de $40 \%$ dos recursos em 2011 , que se repetiu em 2012. A restrição orçamentária enfrentada pela $A B C$ apontou para uma diminuição no comprometimento com novos projetos, levando a Agência a priorizar, principalmente, a execução do que já estava planejado em 2009/2010 e de alguns projetos iniciados em 2011.

Do ponto de vista da sua concepção e implementação, historicamente, e ao longo dos tempos, a cooperação internacional brasileira foi encarada como uma política de Estado, de modo que a cooperação técnica foi, por muitos anos, âmbito de atividade exclusiva do Estado, que detinha o monopólio na formulação e condução das iniciativas concernentes à área (VALLER FILHO, 2007, p. 48). Esta prevalência governamental na condução da cooperação

16 Disponível em: <http://www.abc.gov.br/SobreAbc/Introducao>. 
técnica brasileira vinha sendo, no entanto, relativizada. Apesar da existência de outros atores na implementação de projetos da cooperação oficial do Brasil com os países do Eixo Sul, esta era realizada, em sua grande maioria, por servidores públicos, o que resultou em sérios desafios à eficácia da cooperação devido à alta rotatividade de pessoal, ao acúmulo de responsabilidades domésticas e internacionais, e à experiência insuficiente de trabalho em contextos interculturais (LEITE; SUYAMA; WAISBICH, 2013, p. 6).

\section{A COOPERAÇÃO INTERNACIONAL DO BRASIL PARA O EIXO SUL NA "ERA LULA": ALGUMAS PERCEPÇÕES CRÍTICAS}

A projeção de poder e liderança de um país além das suas fronteiras nacionais, pode se dar por meio da coerção, da cooperação, da difusão de ideias e valores e, também, pela sua capacidade de dinamizar economicamente os países da sua "zona de influência". No entanto, deve existir uma "vontade estratégica consistente e permanente", revelada pela capacidade do Estado na construção de consensos em torno de objetivos internacionais de longo prazo, aliada à "capacidade de planejar e implementar ações de curto e médio prazo através das agências estatais, em conjunto com os atores sociais, políticos e econômicos relevantes" (FIORI, 2013, p. 51-52).

O Brasil sob a gestão do presidente Lula empreendeu transformações significativas no seu discurso ${ }^{17}$ e, também, na prática relativa à sua política externa, de um modo geral, e à cooperação internacional para o desenvolvimento mais especificamente. As transformações discursivas foram, nesta perspectiva, decisivas para posicionar o país no sistema internacional, uma vez que o discurso do Estado se constitui em um elemento determinante, em especial no campo da política externa e da diplomacia, para a definição deste posicionamento. Assim, o Brasil fortaleceu, durante o governo Lula, a vocação multilateral da sua política externa e

\footnotetext{
${ }^{17}$ Dentre a transformações discursivas incorporadas pelo presidente Lula acerca da cooperação internacional, destacamos a ênfase na solidariedade e na dívida histórica, esta última particularmente voltada aos países africanos. De acordo com Saraiva (2012), esse eixo argumentativo da dívida histórica contrapõe-se ao argumento culturalista.
} 
enfatizou a necessidade de uma profunda reforma das instituições multilaterais, em especial do Conselho de Segurança da ONU, o qual pleiteava integrar na condição de membropermanente, pleito que, para Garcia (2013) representava uma demanda de um país em busca de maior projeção no mundo.

A expansão da cooperação internacional brasileira refletia, enfim, o avanço do seu poder econômico e político. Refletia a construção feita pelo país na busca de ocupar outro lugar no cenário internacional que tinha como uma das suas bases a atuação no âmbito da cooperação internacional para o desenvolvimento, em especial, na sua vertente Sul-Sul. A consolidação do país como doador na cooperação internacional, e o aumento da ajuda demandada e fornecida colocaram na pauta de discussão do governo e da sociedade brasileira a necessidade de tratar os termos da sua cooperação com maior profundidade; no entanto, estas mudanças ainda estavam em processo de assimilação, faltando solidificar suas diretrizes e agendas para a cooperação do país.

A redução progressiva da cooperação técnica recebida do exterior e, no caso da cooperação multilateral, a substituição do tradicional viés de cooperação Norte-Sul por novos modelos de relações que envolvessem a concepção, experimentação e validação conjunta de novas práticas, no âmbito de políticas públicas inovadoras e/ou estratégicas para o governo brasileiro, marcou o período. Em apoio à cooperação Sul-Sul bilateral, o Brasil celebrou parcerias com governos de países desenvolvidos e organismos internacionais para a implementação de programas e projetos trilaterais. Segundo Rossi (2011), o país passou a fornecer mais do que receber no âmbito da ajuda internacional entre governos e agências multilaterais. No entanto, mesmo com os avanços e o novo patamar alcançado pelo país no cenário internacional, percebe-se que, apesar de haver uma ideia geral de princípios, faltou uma política de cooperação internacional brasileira que definisse "em primeiro lugar o que somos e o que queremos ser como um país doador, além de simplesmente prestar cooperação na prática" (ROSSI, 2011, p. 5). A atuação do país na cooperação internacional mostrou, portanto, avanços, mas também contradições.

Uma das importantes questões postas para a análise da cooperação brasileira no período diz respeito à existência ou não de um programa oficial de cooperação internacional 
do país, assunto que, por si, configura um divisor de opiniões. O governo brasileiro, ao se referir a sua cooperação internacional, fazia menção clara à existência de um Programa de Cooperação Oficial já constituído; no entanto, esta não era uma ideia unânime entre especialistas na temática, membros do próprio governo, da Academia ou de organizações da sociedade civil. Dentre as questões levantadas para negar a sua existência, destaca-se a falta de planejamento de suas ações e a ausência de diretrizes, objetivos e metas claramente estruturados. Havia ainda uma queixa reincidente relativa à estrutura existente para a execução da cooperação brasileira, faltando ainda maior clareza na política e uma perspectiva concreta de se pensar a cooperação no longo prazo.

A falta de planejamento da cooperação internacional brasileira, conforme Leite (2012), denotava um certo "amadorismo" que podia ser um reflexo de ser este um tema novo na agenda do país. O caráter de atuação a partir do que lhe era demandado pelos outros países, assumido pelo Brasil, seria, deste modo, um impeditivo da realização de um planejamento das ações no longo prazo, o que terminou por atrapalhar a perspectiva de uma contribuição efetiva com o país parceiro. A fragilidade da $A B C$ e sua subordinação ao Itamaraty também são elementos relevantes para se compreender os percalços enfrentados pela cooperação brasileira e a dificuldade em firmar um Programa de Cooperação bem estruturado. Nesta perspectiva, parece-nos que o maior problema não consistia na subordinação da $A B C$, mas na falta de relevância que a agência tinha dentro do Itamaraty. A sua permanência como uma agência deste Ministério não seria impeditiva do seu fortalecimento, desde que o seu perfil se ajustasse a uma lógica de high politics ou, até mesmo, que fosse assumida enquanto um instrumento importante para o soft power do Brasil.

Um aspecto importante refere-se ao fato de que, no Governo Lula, a cooperação brasileira se valorava por ter a "cara do presidente", sendo uma espécie de bandeira do próprio, que acreditava na sua importância para o alcance dos propósitos do país no âmbito internacional. Passou, no entanto, a vivenciar uma espécie de "orfandade", quando este governo chegou ao fim. O orçamento para a cooperação foi impactado nos governos posteriores, denotando a perda de importância da cooperação internacional na agenda brasileira. 
Outro aspecto relevante a ser salientado se refere à intencionalidade da política externa brasileira e da cooperação internacional a esta subjacente. Pode-se dizer que havia uma espécie de "obsessão" do país - protagonizada pelo Itamaraty-, por se tornar um "player importante" na cooperação internacional, como uma estratégia para que o Brasil pudesse figurar como uma "grande potência". Assim, o desejo de protagonismo do país na cooperação Sul-Sul seria menos o resultado de uma identidade com os países do Sul e mais uma atitude baseada nos seus próprios interesses. A cooperação brasileira não era, portanto, um movimento destituído de intencionalidades como muitas vezes pareciam pregar as instâncias oficiais. Neste sentindo, nos parece haver uma estreita relação entre os projetos de cooperação brasileiros e os apoios obtidos dos países africanos na contenda da OMC sobre os subsídios norte-americanos ao algodão e na eleição do brasileiro José Graziano para a direção geral da Organização das Nações Unidas para Alimentação e Agricultura (FAO) ${ }^{18}$, por exemplo.

Segundo Pinheiro (2000, p. 305), uma visão errônea comum é a de que a cooperação entre os Estados implica, necessariamente, algo bom e para o bem. Do mesmo modo, a crença na cooperação desinteressada, tão repetidamente enfatizada nos discursos e documentos oficiais brasileiros, nos parece estar em desacordo com uma realidade de necessidade de jogos de poder, concessões e "favores" mútuos. Nessa perspectiva, diversos autores (AYLLÓN PINO, 2010; LEITE, 2012; LIMA, 2005; MILANI; CARVALHO, 2012) sinalizam que, no bojo da cooperação Sul-Sul brasileira, encontrava-se uma série de questões estratégicas ligadas a sua política externa que vão desde o pleito por um assento permanente no Conselho de Segurança da ONU até a expansão do seu comércio e sua presença no mercado internacional, passando pela disseminação da tecnologia e pela busca de mercados para o biocombustível.

Para Leite (2012, p. 24-25), não há como supor que nas relações que se estabelecem no âmbito da CSS não estejam presentes as relações auto interessadas e de poder. Segundo a autora, estudos empíricos sobre a CSS mostram que considerações políticas e comerciais influenciam, também, a atuação dos doadores emergentes. No entanto, ademais dos possíveis

18 O ex-ministro José Graziano da Silva ganhou a disputa para o cargo de Diretor-Geral da FAO, contra o candidato espanhol Miguel Ángel Moratinos, com 92 votos contra 88. O candidato brasileiro recebeu apoio dos países africanos. Graziano assumiu o cargo de diretor-geral da FAO em 1으 de janeiro de 2012 para um mandato de quatro anos. 
interesses referentes à política externa do país com a CSS, no seu discurso oficial, a cooperação técnica prestada pelo Brasil se definia como sem fins lucrativos, não estando condicionada à compra de bens ou serviços, que buscava atender à demanda dos países em desenvolvimento, fortalecendo-os institucionalmente como condição para a transferência de expertise. Deste modo, o Brasil salientava o respeito à soberania dos países do Eixo Sul com os quais tinha acordo de cooperação e enfatizava o foco de sua cooperação em uma dimensão técnica. Assim, importa refletir sobre a necessidade de um entendimento da assistência técnica como "elemento de uma realidade muito mais ampla, abrangendo as relações econômicas, culturais e políticas", havendo, aí, a necessidade de que as instituições encarregadas da formulação e da gestão da assistência técnica, recebida ou dada, estivessem abertas a um diálogo permanente e ao compartilhamento dos seus poderes decisórios com o setor produtivo, com o establishment científico e acadêmico e com a sociedade civil em geral.

A tensão entre o esforço do governo brasileiro para diferenciar o modelo da CSS empreendido pelo país da tradicional CNS e os riscos de torná-la uma repetição desta, faz parte da realidade vivenciada no período aqui analisado. Se, por um lado, percebemos avanços expressivos no sentido de tentar buscar um caminho diferente, alicerçado na horizontalidade e na solidariedade, por outro emergia a conflitualidade dos interesses políticos e, em alguma medida, econômicos, e a busca pelo poder no cenário internacional. Se, de algum modo, havia uma escuta e um respeito maior ao que demandam os países parceiros aliada à defesa do não condicionamento da cooperação, faltava ainda um foco em resultados que, de fato, determinassem impactos no desenvolvimento dos países. Mostrouse necessário, portanto, um repensar constante dos moldes e caminhos da cooperação que se deseja para não repetir erros cometidos por outros e não incorrer no risco de promover uma espécie de "novo colonialismo".

\section{CONSIDERAÇÕES FINAIS}

A atuação oficial do Brasil na CSS desenhou uma trajetória crescente na primeira década dos anos 2000, particularmente, no período sob o governo do Presidente Lula. O país 
buscou novos caminhos para o "fazer cooperação", embora ainda incorrendo no risco da repetição de velhos e ultrapassados modelos que a história já mostrou serem insuficientes e, por vezes, maléficos. Parecia, entretanto, tatear na busca de um percurso possível, dentro e fora das suas fronteiras, para equilibrar as demandas dos países do Sul, o pleito da sociedade brasileira e o projeto traçado para si, no âmbito de sua política externa, com vistas a uma ascensão e influência no cenário internacional.

O nosso olhar, neste trabalho, esteve voltado para este mundo do início dos anos 2000 cuja geopolítica esteve marcada por inúmeras mudanças, muitas das quais decorrentes da entrada em cena de novos atores da política internacional. Mundo cuja cooperação internacional passava por profundas transformações que transitavam da crise da AOD nos moldes do CAD da OCDE à definição de novas práticas e atores de cooperação. Esteve, particularmente, voltado para o Brasil durante o período compreendido entre 2003 e 2010, sob a presidência de Lula, o qual explicitava uma dualidade que o colocava, ao mesmo tempo, como uma "potência emergente" e repleto de desigualdades sociais e econômicas.

O olhar mais específico para a posição do Brasil no campo da cooperação internacional, mostrou, por sua vez, as marcas de uma inserção dual que esteve expressa na atuação oficial do país no campo, transitando entre o papel de "doador" e, ao mesmo tempo, de "receptor", mas, sobretudo, atuando nos marcos de uma cooperação Sul-Sul que marcou as relações que se estabeleceram e que fizeram história na relação do país com os seus pares do Sul.

A análise da cooperação internacional do Brasil na "Era Lula" nos mostrou avanços significativos nas relações do país neste âmbito, mas também expôs fragilidades e contradições. Remeteu-nos à ideia de que é necessário não esquecer, que os aprendizados com o histórico da CID são fundamentais para a construção de uma política de cooperação internacional atenta a não repetir as mazelas da cooperação do Norte. Neste sentido, cabe à cooperação internacional e aos diferentes atores que com ela interagem, ou que dela fazem parte, um olhar para o passado que permita visualizar a trajetória cumprida, repensar as práticas e as alianças construídas (e desconstruídas) assim como os elementos motivadores da própria cooperação. Cabe, quiçá, uma reflexão sobre a própria razão da sua existência, para que se possa pensar sobre a ideia de sua existência futura. 


\section{REFERÊNCIAS}

ALMEIDA, Elga Lessa de. Do outro lado do Atlântico: As relações políticas e econômicas entre o Brasil e os países africanos desde o século XX. In: KRAYCHETE, Elsa S. (org.). Brasil-África: Cooperação e Investimentos. Feira de Santana: UEFS Editora, 2019.

AYLLÓN PINO, Bruno. La cooperación de Brasil: un modelo en construcción para una potencia emergente. Análisis del Real Instituto Elcano - ARI, n. 143, Real Instituto Elcano. Madrid, 6 oct. 2010. Disponível em:

<http://www.realinstitutoelcano.org/wps/portal/rielcano/contenido?WCM_GLOBAL_CONTE XT=/elcano/elcano_es/zonas_es/ari143-2010>. Acessado em: 22 mar. 2012.

AYLLÓN PINO, Bruno; LEITE, lara Costa. O Brasil e a Cooperação Sul-Sul: contribuições e desafios. Boletim Meridiano 47, v. 10, n. 113, p. 17-18, 2009.

AYLLÓN PINO, Bruno; LEITE, Iara Costa. O Brasil e a cooperação Sul-Sul: um balanço. Ceiri Notícias, 1 jan. 2010. Disponível em: <http://blogceiri.com.br/o-brasil-e-a-cooperacao-sulsul-um-balanco/>. Acesso em: 20 jan. 2012.

BARBOSA, Pedro Henrique Batista. O Brasil e a Embrapa: o viés instrumental da cooperação técnica horizontal. Brasília: Ministério das Relações Exteriores, Instituto Rio Branco, 2011. Mimeo.

BUSS, Paulo Marchiori; FERREIRA, José Roberto. Brasil e saúde global. In: PINHEIRO, Letícia; MILANI, Carlos R. S. Política Externa Brasileira: as práticas da política e a política das práticas. Rio de Janeiro: FGV, 2012. p. 241-265.

CANDEAS, Alessandro. Educação e política externa: por uma parceria diplomaciauniversidade. In: PINHEIRO, Letícia; MILANI, Carlos R. S. Política Externa Brasileira: as práticas da política e a política das práticas. Rio de Janeiro: FGV, 2012. p. 181-199.

CERVO, Amado Luiz. Socializando o desenvolvimento: uma história da cooperação técnica internacional do Brasil. Revista Brasileira de Política Internacional, Brasília, Instituto Brasileiro de Relações Internacionais, v. 37, n. 1, p. 37-63, 1994. Disponível em: <https://docs.google.com/file/d/1TF0MZCmbQBqgzTAiB_4HhEcVwZeSCcr7IrDon6rPYfvMYY VM6mhRk4LUdiYt/edit?usp=drive_web\&pli=1>. Acesso em: 10 dez. 2011.

COMISIÓN ECONÓMICA PARA AMÉRICA LATINA Y EL CARIBE- CEPAL. A cooperação internacional no novo contexto mundial: reflexões desde América Latina e Caribe. Notas da Secretaria. jun. 2010. Disponível em: 
<http://www.eclac.cl/pses33/noticias/paginas/7/39037/2010-223-SES-33-

11_Cooperacao_internacional.pdf>. Acessado em: 16 abr. 2012.

CORDEIRO, Rui Mesquita. De receptor a doador: os desafios da cooperação para o desenvolvimento na política externa brasileira sob a ótica da relação estado/sociedade civil. Monções: Revista de Relações Internacionais da UFGD, Dourados, v.1, n.2, p. 140-163, jul./dez. 2012. Disponível em:

<http://www.periodicos.ufgd.edu.br/index.php/moncoes/article/view/2120/1339>. Acesso em: 11 abr. 2013.

CORRÊA, Márcio Lopes. Dinâmicas que marcaram a cooperação internacional no Brasil nas últimas décadas. Revista da Rede de Humanização do Desenvolvimento: Redes de Cooperação, Brasília, IABS, v. 1, n. 1,p. 14-18, ago. 2011. Disponível em: <http://api.ning.com/files/q*WvWmFgHDbAJQp62F050j8hbTh3t7hWwE*2BsaU1Z7EbXe4M eoaEULLfGcIQvZSICeteISkVQKn9eaKOwFIDJ1*_

W4Es7h6/Revista_Rede_Humanizao_Desenvolvimento_WEB2.pdf>. Acesso em: 20 abr. 2012.

FIORI, José Luís. O Brasil e seu “entorno estratégico" na primeira década do século XXI. In: SADER, Emir (Org.). 10 anos de governos pós-neoliberais no Brasil: Lula e Dilma. São Paulo: Boitempo; Rio de Janeiro: FLACSO Brasil, 2013.

FIORI, José Luis. Poder, geopolítica e desenvolvimento. Carta Maior. 2013. Disponível em: https://www.cartamaior.com.br/?/Coluna/Poder-geopolitica-e-desenvolvimento/28779. Acessado em 20 de junho de 2021.

GARCIA, Marco Aurélio. Dez anos de política externa. In: SADER, Emir (Org.). 10 anos de governos pós-neoliberais no Brasil: Lula e Dilma. São Paulo: Boitempo; Rio de Janeiro: FLACSO Brasil, 2013.

GONÇALVES, Fernanda Cristina Nanci Izidro. Cooperação Sul-Sul e política externa: um estudo sobre a participação de atores sociais. Dissertação (Mestrado em Relações Internacionais) - Pontifícia Universidade Católica do Rio de Janeiro. Rio de Janeiro, 2011. Mimeo. Disponível em: <http://www.maxwell.lambda.ele.pucrio.br/Busca_etds.php?strSecao=resultado\&nrSeq=18600@1>. Acesso em: 10 maio 2013.

HIRST, Monica. Países de renda média e a cooperação Sul-Sul: entre o conceitual e o político. In: LIMA, Maria Regina Soares de; HIRST, Monica (Org.). Brasil, Índia e África do Sul: desafios e oportunidades para novas parcerias. São Paulo: Paz e Terra, 2009.

HIRST, Mônica. America Latina y la Cooperación Sur-Sur: reflexiones conceptuales y políticas. In: AYLLÓN, Bruno; SURASKY, Javier (Coord.). La Cooperación Sur-Sur en Latinoamérica: utopía y realidad. Madrid: La Catarata; Instituto Universitario de Desarrollo, 2010. 
INSTITUTO DE ESTUDOS SOCIOECONÔMICOS - INESC; CHRISTIAN AID. Presente e futuro: tendências na Cooperação Internacional Brasileira e o Papel das Agências Ecumênicas. Brasília: INESC, 2012. Disponível em:

<http://www.inesc.org.br/biblioteca/publicacoes/livros/2012/presente-e-futuro-tendenciasna-cooperacao-internacional-brasileira-e-o-papel-das-agencias-ecumenicas/view $>$. Acesso em: 10 jan. 2013.

IPEA. Cooperação Brasileira para o Desenvolvimento Internacional: 2005-2009. Secretaria de Assuntos Estratégicos da Presidência da República (SAE/PR); Instituto de Pesquisa Econômica Aplicada (Ipea); Ministério das Relações Exteriores (MRE); Agência Brasileira de Cooperação (ABC). Brasília, 2010.

IPEA. Cooperação brasileira para o desenvolvimento internacional: 2011 - 2013. Instituto de Pesquisa Econômica Aplicada; Agência Brasileira de Cooperação. - Brasília: IPEA: ABC, 2016. 184 p.

KLEIMAN, Alberto; CEZARIO, Gustavo de Lima. Um olhar sobre a ação internacional dos governos subnacionais. 2012. In: PINHEIRO, L.; MILANI, Carlos R. S. Política Externa Brasileira: as práticas da política e a política das práticas. Rio de Janeiro: FGV, 2012. 352p. p. 301-329.

LEITE, lara Costa. Cooperação Sul-Sul: conceito, história e marcos interpretativos. Observador On-line, v. 7, n. 3, mar. 2012. Disponível em: <http://www.opsa.com.br/images/pdf/observador/observador_v_7_n_03_2012.pdf>. Acesso em: 11 abr. 2013.

LEITE, lara Costa; SUYAMA, Bianca; WAISBICH, Laura Trajber. Para além do tecnicismo: a Cooperação Brasileira para o Desenvolvimento Internacional e caminhos para sua efetividade e democratização. Policy Brief, jul. 2013. Disponível em: <http://www.cebrap.org.br/v2/files/upload/biblioteca_virtual/item_796/26_08_13_14Polic y_Briefing_Para\%20al\%C3\%A9m\%20do\%20tecnicismo.pdf>. Acesso em: 20 out. 2013.

LE MONDE DIPLOMATIQUE - BRASIL. Brasil, América Latina e a Cooperação Internacional. Encarte especial, ago. 2011. Disponível em: <http://www.diplomatique.org.br/ edicoes_anteriores.php?pagina=3>. Acesso em: 10 dez. 2012.

LESSA, Mônica Leite; SARAIVA, Miriam Gomes; MAPA, Dhiego de Moura. Entre o palácio do Itamaraty e o Palácio Capanema: perspectivas e desafios de uma diplomacia cultural no governo Lula. P. 95-120. In: PINHEIRO, L.; MILANI, Carlos R. S. (org.). Política Externa Brasileira: as práticas da política e a política das práticas. Rio de Janeiro: Editora FGV, 2012. $352 p$. 
LIMA, Maria R. Soares de. A política externa brasileira e os desafios da cooperação Sul-Sul. Revista Brasileira de Política Internacional, v. 48, n. 1, p. 24-59, 2005. Disponível em: <http://www.scielo.br/pdf/rbpi/v48n1/v48n1a02.pdf>. Acesso em: 14 maio 2013.

LOPES, Luara Landulpho Alves. O Brasil no regime da cooperação internacional para o desenvolvimento: quoi de neuf? In: ENCONTRO NACIONAL ABRI, 3. São Paulo, 2011.

Proceedings online... Associação Brasileira de Relações Internacionais, Instituto de Relações Internacionais, USP. Disponível em:

$<$ http://www.proceedings.scielo.br/scielo.php?script=sci_arttext\&pid=MSC00000001220110 00300008\&lng=en\&nrm=abn>. Acesso em: 29 jul. 2013.

MAWDSLEY, Emma. Non-DAC donors and the changing landscape of foreign aid: the (in)significance of India's development cooperation with Kenya. Journal of Eastern African Studies, v. 4, n. 2, p. 361-379, 2010.

MAWDSLEY, Emma. The changing geographies of foreign aid and development cooperation: contributions from gift theory. Transactions of the Institute of British Geographers. Wiley Online Library, 6 set. 2011. Disponível em: <http://dc366.4shared.com/doc/8rxRcexW/preview.html>. Acesso em: 11 jan. 2012.

MILANI, Carlos R. S.; CARVALHO, Tássia. Cooperação Sul-Sul e Política Externa: a presença de Brasil e China no continente africano. Rio de Janeiro. 2012. Mimeo.

MILANI, Carlos R. S. Solidariedade e Interesse: Motivações e Estratégias na Cooperação Internacional para o Desenvolvimento. Curitiba: Apris, 2018.

PUENTE, Carlos Alfonso Iglesias. A cooperação técnica horizontal brasileira como instrumento da política externa: a evolução da cooperação técnica com países em desenvolvimento - CTPD - no período 1995-2005. Brasília: FUNAG, 2010. Disponível em: <http://www.funag.gov.br/biblioteca/dmdocuments/Cooperacao_tecnica_brasileira.pdf>. Acesso em: 18 out. 2012.

ROSSI, Amanda. Brasil, um país doador. Le Monde Diplomatique Brasil, São Paulo, abr. 2011. Disponível em: <http://diplomatique.uol.com.br/artigo.php?id=910>. Acesso em: 20 abr. 2013.

SARAIVA, José Flávio Sombra. África parceira do Brasil atlântico: relações internacionais do Brasil e da África no início do século XXI. Belo Horizonte, MG: Fino Traço, 2012.

VALLER FILHO, Wladimir. O Brasil e a crise haitiana: a cooperação técnica como instrumento de solidariedade e de ação diplomática. Brasília: FUNAG, 2007. 396p. Disponível em: <http://www.funag.gov.br/biblioteca/dmdocuments/0375.pdf>. Acesso em: 15 out. 2013. 
VELASCO E CRUZ, Sebastião. O futuro da política externa brasileira: desafios e perspectivas. Brasil no Mundo - Contribuições para a Política Externa Brasileira [online]. 25 jul. 2013. Disponível em: <http://blogbrasilnomundo.wordpress.com/2013/07/25/o-futuro-dapolitica-externa-brasileira-desafios-e-perspectivas/>. Acesso em: out. 2013.

ZIMMERMANN, Felix; SMITH, Kimberly. More actors, more money, more ideas for International Development Co-operation. Journal of International Development. J. Int. Dev., OECD Development Co-operation Directorate, Paris, France, v 23, n. 5, p. 722-738, jul. 2011. 